\title{
Effects of Physicochemical/Mineralogical Characteristics of Limestones and Porosity after Calcination on Desulfurization Reactivities
}

\author{
Chul-Seoung Baek ${ }^{* * * *}$, Jun-Hyung Seo*, Jin-Sang Cho*, Kye-Hong Cho*, and Choon Han***, \\ *Department of Research and Development, Korea Institute of Limestone and Advanced Materials, Danyang 27003, Korea \\ **Department of Chemical Engineering, Kwangwoon University, Seoul 01897, Korea
}

(Received December 17, 2015; Revised January 12, January 18, 2016; Accepted January 19, 2016)

\begin{abstract}
Characteristics of wet flue gas desulfurization and in-furnace desulfurization of domestic and overseas limestone with different crystallinity and crystalline size are studied in this article. Properties of desulfurization were evaluated in relation to physicochemical/ mineralogical characteristics, degree of pore formation for different calcination temperatures and TNC(total neutralizing capability). TNC of domestic high crystalline limestone was lower than that of overseas one. On the other hand, the porosity after calcination was shown to be relatively high for domestic limestone, which had high initial rates of desulfurization reactions in-furnace. Based on low pore formation and porosity with high TNC of crystalline high-Ca limestones compared to macrocrystalline ones, the former are preferred for wet desulfurization processes.
\end{abstract}

Key words : Limestone, Desulfurization, Calcination, Porosity, Total neutralizing capability

\section{Introduction}

$\mathrm{S}$ ulfur oxides containing sulfur dioxide gas discharged from coal power plants using combustion coal act as the major cause for acid rain and smog. Korea has made mandatory the installation of flue-gas desulfurization facilities mandatory by 2000 in coal power plants discharging a large amount of sulfur oxides, and induced reduction through regulations on high-level emission allowances in the case of new construction. According to the 2014 environment statistical yearbook published by Ministry of Environment of Korea, the emission from the energy industry part of gaseous sulfur oxide including sulfur dioxide gas has been reduced from the peak in 1996, down to 190,000 tons in 2003 and 81,000 tons in 2010.

However, due to additional construction of new coal power plants resulting from the explosive increase in demands for electric power as well as the increased use of low-grade coal with economy and high effects on supply stability, possibilities of an increase in the sulfur oxide emission from the overall energy industry are being heightened. ${ }^{1,2)}$ Lime used as a representative desulfurizing absorbent is petrologically one of carbonate rocks and includes calcite, low-Mg calcite, high-Mg calcite, $\mathrm{Mg}$ calcite and aragonite in the crystalline state along with clastic condition in the noncrystalline state depending on the mineral structure and composition, and there exist a variety of sizes from crypto-crystalline (smaller

${ }^{\dagger}$ Corresponding author: Choon Han

E-mail : chan@kw.ac.kr

Tel : +82-2-940-5175 Fax : +82-2-909-0667 than $0.004 \mathrm{~mm}$ ) to very coarse-crystalline (larger than $1 \mathrm{~mm}$ ) depending on the size of mineral crystals. And differences in chemical reactivity and activity occur due to a difference in chemical composition ratios of minor components contained in the limestone such as $\mathrm{Al}_{2} \mathrm{O}_{3}, \mathrm{Fe}_{2} \mathrm{O}_{3}, \mathrm{SiO}_{2}$ etc. Accordingly, analyses of desulfurization characteristics for limestones by the unit of mining place are being conducted in a long term in relation to studies on efficiency improvement for limestones used in not only wet desulfurization reactions but also dry desulfurization processes allowing additional installation in the existing power plants and infurnace desulfurization processes for the circulating fluidized bed boilers which succeeded in scale-up. ${ }^{3,4)}$

High-temperature dry desulfurization process using limestone, etc. as an absorbent is a reaction where sulfur oxides are adsorbed under the high-temperature reaction condition above $850^{\circ} \mathrm{C}$ which is higher than the absorption reaction temperature of $150 \sim 200^{\circ} \mathrm{C}$ for general lime spray drying (LSD) and duct sorbent injection (DSI) processes and $500 \sim 750^{\circ} \mathrm{C}$ for economizer sorbent injection(ESI) process. Only oxides of some elements such as $\mathrm{Ca}, \mathrm{Zn}, \mathrm{Fe}, \mathrm{Mn}$, V, etc. are applicable, and limestone as a Ca-based absorbent is known to have the highest economy when supply stability and economy are considered. Types of desulfurization processes may be classified according to recycling status and desulfurization reaction method as shown in Fig. 1 below. Most of the domestic power plant companies operate the forced oxidation process of limestone-gypsum as a transformed form of LSFO process, owing to the fact that gypsum with a commodity value can be produced. In the case of dry desulfurization process, it is subdivided according to the injection position(duct, economizer, absorber and furnace) of 


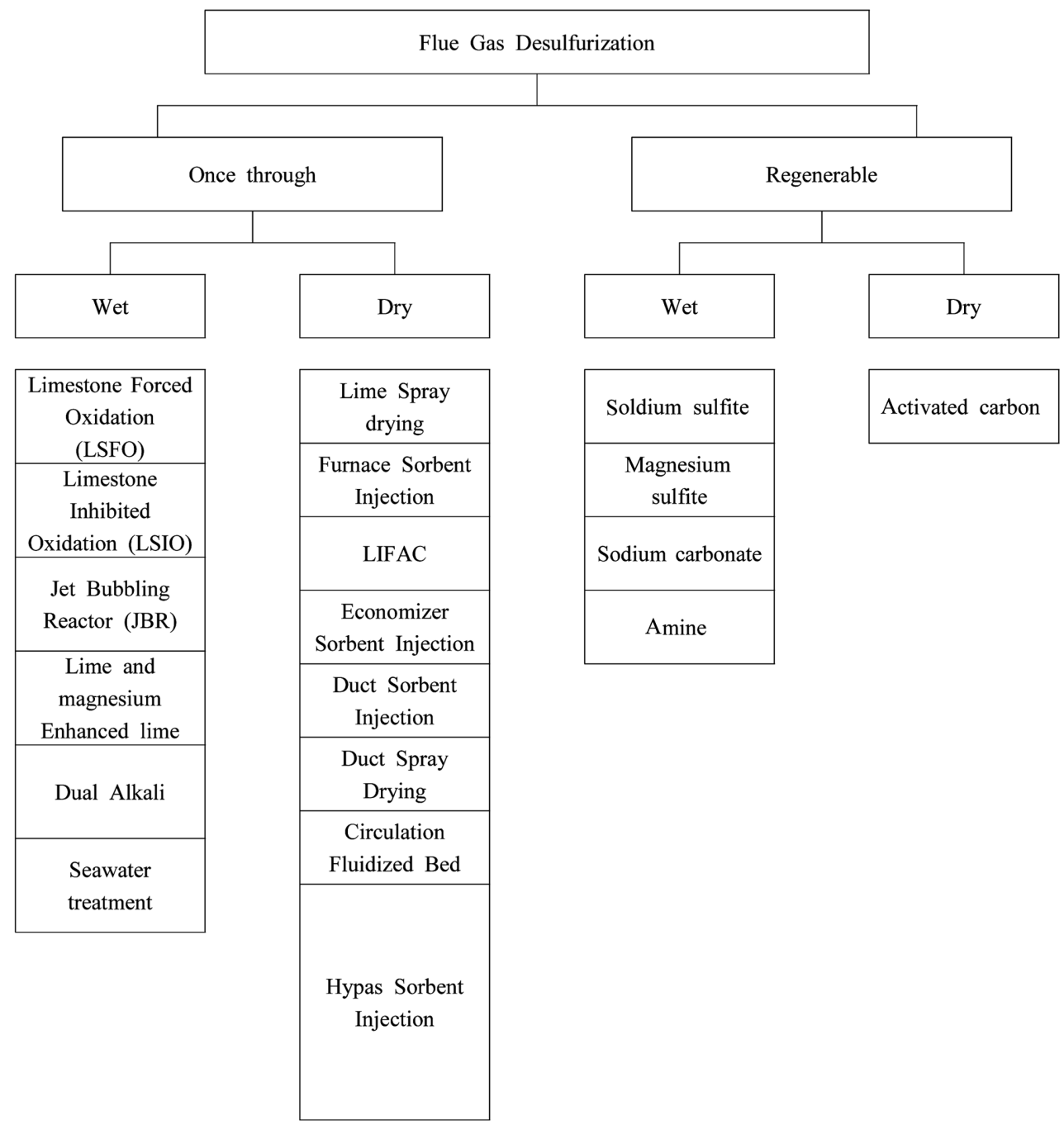

Fig. 1. Classification of flue gas desulfurization process according to once through \& regenerable.

the absorbent and the reaction temperature. ${ }^{5)}$

Wet desulfurization reaction is a reaction where dissolution reaction of sulfur oxide gas and desulfurization reaction of desulfurizing absorbent occur simultaneously. As shown by the following equation 1 , dissolution rates of $\mathrm{SO}_{2}$ in a gaseous state are determined by partial pressure and concentration conditions. Since desulfurization reaction of the equation 2 is a reaction of lowering the concentrations of $\mathrm{H}^{+}$ and $\mathrm{HSO}_{3}^{-}$, neutralization rates of the limestone act as an important factor.

- [Wet desulfurization process, low temperature]

$$
\begin{aligned}
& \mathrm{SO}_{2}(\mathrm{~g})+\mathrm{H}_{2} \mathrm{O} \rightarrow \mathrm{SO}_{2} \cdot \mathrm{H}_{2} \mathrm{O} \rightarrow \mathrm{H}^{+}+\mathrm{HSO}_{3}^{-} \\
& \mathrm{H}^{+}+\mathrm{CaCO}_{3} \leftrightarrow \mathrm{Ca}^{2+}+\mathrm{HSO}_{3}^{-}+2 \mathrm{H}_{2} \mathrm{O} \\
& \quad \leftrightarrow \mathrm{CaSO}_{3} \cdot 2 \mathrm{H}_{2} \mathrm{O}+\mathrm{H}^{+}
\end{aligned}
$$

High-temperature dry desulfurization reaction in circulating fluidized bed boilers with limestone being employed as an absorbent is a reaction where calcination reaction of the following equation 3 , stepwise desulfurization reaction such as the equations 4 and 5, 'two phase heterogeneous reaction' such as the equations 6 and 7 occur simultaneously at a high temperature. Each reaction phase such as this is affected by factors different from those for wet desulfurization reaction such as temperature of reactor, composition of gas inside the reactor, size of limestone particles, etc. ${ }^{6}$

- $\left[\mathrm{CaCO}_{3}\right.$ calcination, about $\left.850^{\circ} \mathrm{C}\right]$

$\mathrm{CaCO}_{3}(\mathrm{~s}) \rightarrow \mathrm{CaO}(\mathrm{s})+\mathrm{CO}_{2}(\mathrm{~g})$

$\Delta \mathrm{H}=182.1 \mathrm{~kJ} / \mathrm{gmol}$

- $\left[\mathrm{CaO}\right.$ desulfurization, about $\left.450^{\circ} \mathrm{C}\right]$

$\mathrm{CaO}+\mathrm{SO}_{2} \rightarrow \mathrm{CaSO}_{3}$

- $\left[\mathrm{CaO}\right.$ desulfurization, above $\left.740^{\circ} \mathrm{C}\right]$

$\mathrm{CaO}+\mathrm{SO}_{2}+1 / 2 \mathrm{O}_{2} \rightarrow \mathrm{CaSO}_{4} \quad \Delta \mathrm{H}=-481.4 \mathrm{~kJ} / \mathrm{gmol}$

-[desulfurization in the absence of Oxygen, above $830^{\circ} \mathrm{C}$ ] $4 \mathrm{CaSO}_{3} \rightarrow 3 \mathrm{CaSO}_{4}+\mathrm{CaS}$ 
- [CaS oxidized to $\mathrm{CaSO}_{4}$, above $830^{\circ} \mathrm{C}$ ]

$\mathrm{CaS}+2 \mathrm{O}_{2} \rightarrow \mathrm{CaSO}_{4}$

Calcium oxide with calcination reaction completed according to the in-furnace desulfurization reaction of the equation 3 exists as $\mathrm{CaSO}_{3}$ up to $450^{\circ} \mathrm{C}$ as in the equation 4 , as a mixture of $\mathrm{CaSO}_{3}$ and $\mathrm{CaSO}_{4}$ up to $740^{\circ} \mathrm{C}$, and then only as $\mathrm{CaSO}_{4}$ above $740^{\circ} \mathrm{C}$ as in the equation 5 . And, when oxygen in the atmosphere is insufficient, it exists as a mixture of $\mathrm{CaS}, \mathrm{CaSO}_{3}$ and $\mathrm{CaSO}_{4}$ as in the equation 6, only as a mixture of $\mathrm{CaS}$ and $\mathrm{CaSO}_{4}$ above $830^{\circ} \mathrm{C}$ as in the equation 6 , and $\mathrm{CaS}$ is oxidized to be converted to $\mathrm{CaSO}_{4}$ at a high temperature when oxygen is sufficient as in the equation $7 .^{7)}$ And in terms of the overall reaction rate, only $56.7 \%$ of the total calcium composition can participate in desulfurization reaction in a theoretical dry reaction process since the molar volume of $\mathrm{CaSO}_{4}$ as the reaction product is larger than that of $\mathrm{CaCO}_{3}$ or $\mathrm{CaO}$. Thus, desulfurization efficiencies may be expected to be determined by pore plugging and pore mouth closure phenomena caused by the pores produced on $\mathrm{CaO}$ surfaces.

Desulfurization process of limestone in the particle and pore model is divided into diffusion of $\mathrm{SO}_{2}$ and $\mathrm{O}_{2}$ within the gas film outside particles, diffusion of $\mathrm{SO}_{2}$ and $\mathrm{O}_{2}$ in pores inside the particles and solid diffusion in the product layer. ${ }^{8,9)}$ Since the reaction gas required for desulfurization reaction in such diffusion processes reaches inlet and surface of the limestone particles first, it acts as the cause for expansion and closure of the surrounding area of pore surface or increase in the diffusion distance, resulting in reduction of desulfurization efficiencies. Thus, intial pore structure and pore size produced in the calcination process of limestone act as an important factor for the kinetics of gas-solid reactions.

In the present study, in-furnace desulfurization technology and market applied for circulating fluidized bed boiler (CFBC) domestically taking the spotlight as one of the clean power generation technologies were analyzed, and 4 types of limestone mined from Donghae-Samcheok region, 1 type of limestone from Jecheon-Danyang region and 2 types of calcite from Europe region were selected among the limestones used as an in-furnace desulfurization absorbent and optical microscope observation was conducted by using thin sections for mineralogical characteristics analysis. And reactivities of limestones were evaluated through ASTM C1318-95 for total neutralizing capability experiment of desulfurizing limestone and lime. ${ }^{5)}$ To evaluate pore volume and pore size acting as the major factors for desulfurization reaction characteristics, surface observation and porosity analysis for the limestone calcined at $850^{\circ} \mathrm{C}, 950^{\circ} \mathrm{C}$ and $1,050^{\circ} \mathrm{C}$, respectively, were conducted by using a scanning electron microscope (SEM) and a porosity meter. Through these methods, the characteristics of limestones suitable for in-furnace desulfurization application were considered.

\section{Experimental Procedure}

For the desulfurizing absorbent samples, 4 types of Pungchon formation limestone located in Donghae-Samcheok region $(\mathrm{A} \sim \mathrm{D}), 1$ type of Gapsan formation limestone located in Jecheon-Danyang region and 2 types of overseas limestone (F, G) were employed. Among these samples, the limestone from Donghae-Samcheok region was used by one domestic CFBC power plant in the past, and selected as an increase in its future usage was expected when economy and proximity were considered. In the case of the limestone from Jecheon-Danyang region, it was affirmed to be used by a private power plant company as well as some industry areas and hence was selected although economy tended to be low due to its mining method, the transportation distance, etc. In the case of overseas limestones, crystalline, high-class limestone from Graz region of Austria known to have been generated in the paleozoic era Devonian $\operatorname{period}(\mathrm{F})$ and crystalline limestone from Milano region known to have been generated in the mesozoic era upper Jurassic period $(G)$ were selected since they were considered to be appropriate as the control group due to their high similarity in geological and mineralogical characteristics to those of domestic limestones.

The samples collected per mine were dried at $110^{\circ} \mathrm{C}$ after undergoing cleaning process to remove foreign objects from surfaces. After preparation of thin sections by using a cutter and a grinder for optical analysis, crystalline phase analysis was conducted through a polarization microscope (Olympus, BX51, Japan).

For physicochemical analysis, each type of samples was pulverized into a size less than $5 \mathrm{~mm}$ and an average density of the sample was measured by using a gas density meter (Pro-tech, Accupyc 1340, Korea). And after execution of fine pulverization per sample to obtain sizes smaller than $\mathrm{d}_{90}=44 \mu \mathrm{m}$, thermogravimetric differential scanning thermal analysis (NETZSCH, STA 449C Jupiter, Germany), Xray fluorescence analysis (Rigaku, primus-2, Japan), X-ray diffraction analysis (Rigaku, D/MAX 2500 V/PC, Japan) were conducted.

To predict in-furnace desulfurization and wet performance of desulfurizing limestones, surface observation using a scanning electron microscope, porosity measurement and total neutralizing capability experiment using ASTM experiment method were conducted following calcination. Evaluation methods for the wet desulfurization performance utilizing limestones may be divided into the batch type and the continuous type. In the case of batch type, there are limitations in evaluation of desulfurizing efficiencies in continuous process flows although quantitative evaluations for particular desulfurizing performance are possible. However, since internationally standardized evaluation regulations for continuous desulfurizing test method have not been established yet, desulfurizing performance has been compared in the present study according to the experimental method of ASTM C 1318-95 'Standard Test 
Method for Determination of Total Neutralizing Capability and Dissolved Calcium and Magnesium Oxide in Lime for Flue Gas Desulfurization (FGD)' which minimized reaction impediments among the batch-type experimental methods. ${ }^{10)}$

For evaluation of in-furnace desulfurizing performance, each limestone sample with its surfaces ground by using a cutter and a grinder was calcined for 1 hour at $850^{\circ} \mathrm{C}, 950^{\circ} \mathrm{C}$, $1,050^{\circ} \mathrm{C}$, respectively, by using a box-type electric furnace under the temperature rise condition of $10^{\circ} \mathrm{C}$ per minute. Surfaces of the samples calcined under each condition were observed through a scanning electron microscope (S-4300, HITACHI, Japan) after being cooled in a desiccator. To check for pore volume and pore size, surfaces of the calcined limestone particles were cut and subjected to examination of pore size and distribution by using a porosity meter (Autopore IV 9520, PRO-TECH, Korea).

To evaluate wet desulfurization performance, each sample was separated into a total of 3 particle sizes consisting of smaller than $0.045 \mathrm{~mm}, 0.045 \sim 0.1 \mathrm{~mm}$ and $0.1 \sim 1.0 \mathrm{~mm}$ according to 'KS A 0517 [General rules for sieving test method]' and subsequently experimented. $1.402 \mathrm{~g}$ of limestone separated per particle size and $50 \mathrm{~mL}$ of distilled water were agitated by using a titrator (SI, Titronic Basic \& Titroline 6000, USA) for 30 minutes, and evaluation was made for total neutralizing capability $\left(\mathrm{TNC}_{(\mathrm{as} \mathrm{CaO})}\right)$ as the usage of $1 \mathrm{~N}$ hydrochloric acid fed until the $\mathrm{pH}$ was maintained at $6 \pm 0.4$. The rate of feeding the hydrochloric acid into a slurry solution containing limestone was set to be 0.2 $\mathrm{mL}$ per 10 seconds, and the condition was maintained for 30 minutes by feeding $0.1 \sim 0.2 \mathrm{~mL}$ upon increase to $\mathrm{pH}$ higher than 6.04 after $\mathrm{pH} 6$ was reached. Three mean values excluding the maximum and the minimum values were utilized as the experimental result among the fed amounts of hydrochloric acid subjected to the experiments repeated for 5 times, respectively. The calculation equation for $\mathrm{TNC}_{(\text {as } \mathrm{CaO})}$ is given by the equation 8 .

$$
\% T N C\left({ }_{a s} \mathrm{CaO}\right)=\frac{A \times B \times C_{1}}{W}
$$

where $\mathrm{A}$ is the consumed amount $(\mathrm{mL})$ of $\mathrm{HCl}$ during 30 minutes, $\mathrm{B}$ the concentration $(\mathrm{N})$ of $\mathrm{HCl}, \mathrm{C}$ the chemical constant (2.804), W the weight (g) of limestone sample.

\section{Results and Discussion}

\subsection{Analysis of limestone characteristics}

After removal of surface contaminants through cleaning process as much as possible from the collected limestones mined at 7 domestic and overseas mines, an optical analysis was performed as shown in Fig. 2. In the case of A and C samples, typical characteristics of Pungchon formation high-class limestones having white-grey colors of almost similar ratios were observed due to the adjacent nature of mines, and the samples were affirmed to be crystalline limestone having relatively uniform crystal sizes. Although B

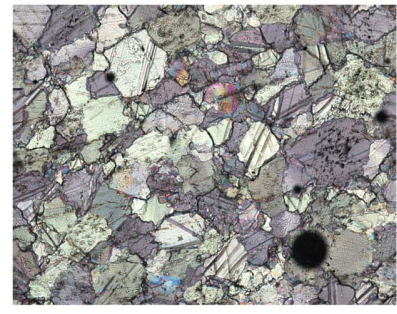

(A)

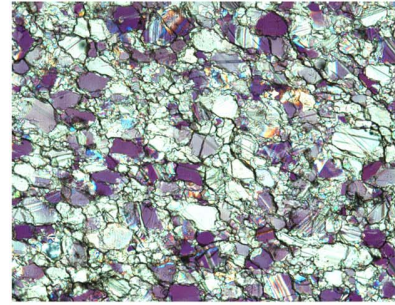

(C)

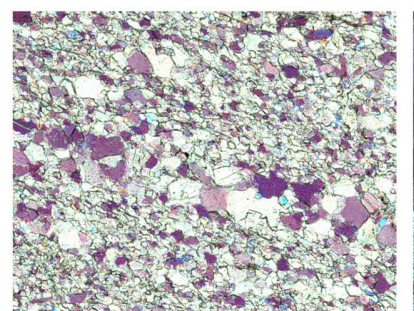

(E)

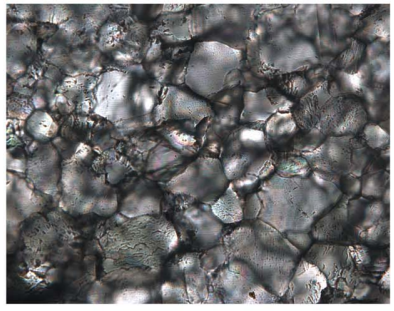

(B)

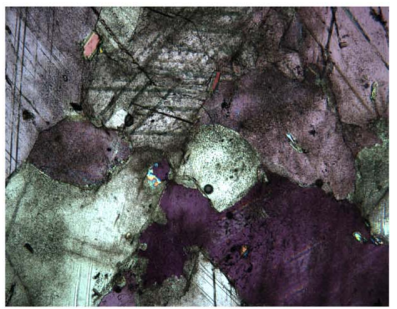

(D)

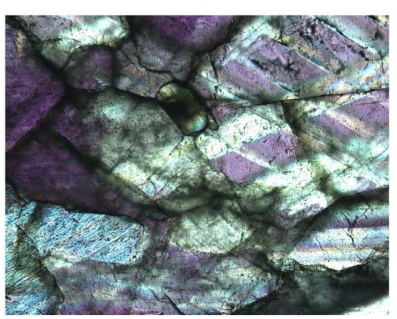

(F)

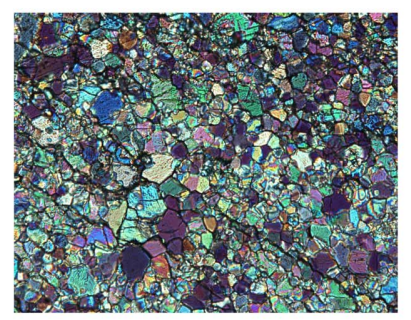

(G)

Fig. 2. Optical micrographs of limestone samples.

and D samples were Pungchon formation limestone from the same generation age, their colors were not uniform due to a large amount of impurities, and affirmed to have an anhedral structure without a unique crystalline form due to hindrance by other minerals along with a hypidiomorphic crystalline structure having an incompletely developed surface for the mineral crystals. E sample as one of the representative Gapsan formation limestone had a crystalline structure which was similar to that of G sample as an overseas limestone, while $\mathrm{F}$ sample showed a typical characteristics inherent to crystalline calcite.

The analysis results for chemical composition using XRF are shown in Table 1. A, C and E samples are high-class limestones with $\mathrm{CaO}$ class higher than $54 \%$. B sample is a limestone satisfying the quality of limestone for in-furnace desulfurization where $\mathrm{MgO}$ composition is relatively higher than that for other samples. In general, Pungchon formation upper limestones have formation of a layer with a 
Table 1. Chemical Composition of Limestone Samples

\begin{tabular}{ccccccccc}
\hline Component(\%) & $\mathrm{A}$ & $\mathrm{B}$ & $\mathrm{C}$ & $\mathrm{D}$ & $\mathrm{E}$ & $\mathrm{F}$ & $\mathrm{G}$ \\
\hline $\mathrm{SiO}_{2}$ & 0.95 & 0.20 & 0.37 & 11.98 & 1.78 & 1.09 & 0.08 \\
$\mathrm{Al}_{2} \mathrm{O}_{3}$ & 0.59 & 0.12 & 0.19 & 3.32 & 0.11 & 0.24 & 0.03 \\
$\mathrm{Fe}_{2} \mathrm{O}_{3}$ & 0.29 & 0.28 & 0.22 & 1.25 & 0.21 & 0.12 & 0.01 \\
$\mathrm{CaO}$ & 54.31 & 50.85 & 54.40 & 46.03 & 54.17 & 54.54 & 55.28 \\
$\mathrm{MgO}$ & 0.49 & 3.80 & 0.95 & 0.90 & 0.65 & 0.56 & 0.73 \\
\hline
\end{tabular}

Table 2. Density of Limestone Samples

\begin{tabular}{cccccc}
\hline Division & Volume $\left(\mathrm{cm}^{3}\right)$ & Volume Deviation $\left(\mathrm{cm}^{3}\right)$ & Density $\left(\mathrm{g} / \mathrm{cm}^{3}\right)$ & Density Deviation $\left(\mathrm{g} / \mathrm{cm}^{3}\right)$ & Temperature $\left({ }^{\circ} \mathrm{C}\right)$ \\
\hline A & 1.8810 & 0.0011 & 2.7561 & 0.0016 & 22.02 \\
B & 2.7759 & 0.0011 & 2.7607 & 0.0001 & 25.65 \\
C & 1.5453 & 0.0029 & 2.7550 & 0.0053 & 21.00 \\
D & 1.9061 & 0.0015 & 2.8318 & 0.0022 & 26.14 \\
E & 1.7137 & 0.0018 & 2.7609 & 0.0029 & 22.55 \\
F & 0.4726 & 0.0012 & 2.7445 & 0.0068 & 24.20 \\
G & 0.4191 & 0.0016 & 2.7120 & 0.0103 & 24.20 \\
\hline
\end{tabular}

bright hue mineralogically resulting from recrystallization with no large deviations having been reported to occur in the chemical composition aspect, and are known to have characteristics containing a large amount of dolomite composition along with a high $\mathrm{CaO}$ content. As affirmed by XRD analysis of Fig. 3. D specimen was affirmed to be a limestone at the level allowed to be used only for cement applications since most impurities contained Quartz $\left(\mathrm{SiO}_{2}\right)$ and Muscovite as a clayey composition. Presence of these impure minerals may be considered in good agreement with an increase in $\mathrm{SiO}_{2}, \mathrm{Al}_{2} \mathrm{O}_{3}$ and $\mathrm{Fe}_{2} \mathrm{O}_{3}$ contents showing distinct differences from other samples as suggested by the $\mathrm{XRF}$ analysis result. Meanwhile, both $\mathrm{F}$ and $\mathrm{G}$ samples are high-class limestones with $\mathrm{CaO}$ contents of more than $54 \%$. $\mathrm{G}$ sample of these had more than $55 \%$ indicating that it was a limestone of very good quality except for a very small amount of dolomite composition, and most of the peaks were identified to be crystalline calcite through XRD analysis.

Density measurement results for each sample are shown in Table 2. All of 5 domestic samples showed a value around $2.75 \mathrm{~g} / \mathrm{cm}^{3}$. In the case of $\mathrm{G}$ sample among the limestones from Europe regions, the repeatedly measured values were $2.72 \mathrm{~g} / \mathrm{cm}^{3}, 2.71 \mathrm{~g} / \mathrm{cm}^{3}$ and $2.69 \mathrm{~g} / \mathrm{cm}^{3}$, respectively, showing slightly lower densities compared with other samples. When the Pungchon formation limestones of A-D samples were compared, densities were shown to have an increasing tendency, the lower the class of $\mathrm{CaO}$, so that the mineral phases including impurities were considered to have an overall effect.

In Fig. 4, TG-DSC analysis results for limestone are shown. All 7 types of samples had an increase in thermal decomposition rates at $700^{\circ} \mathrm{C}$, and the thermal decomposition reaction proceeded most actively in the section of $800 \sim 850^{\circ} \mathrm{C}$. And the reaction was affirmed to have ended at $940 \sim 960^{\circ} \mathrm{C}$, where about $35 \sim 43 \%$ of weight reduction occurred. While thermal decomposition characteristics of A

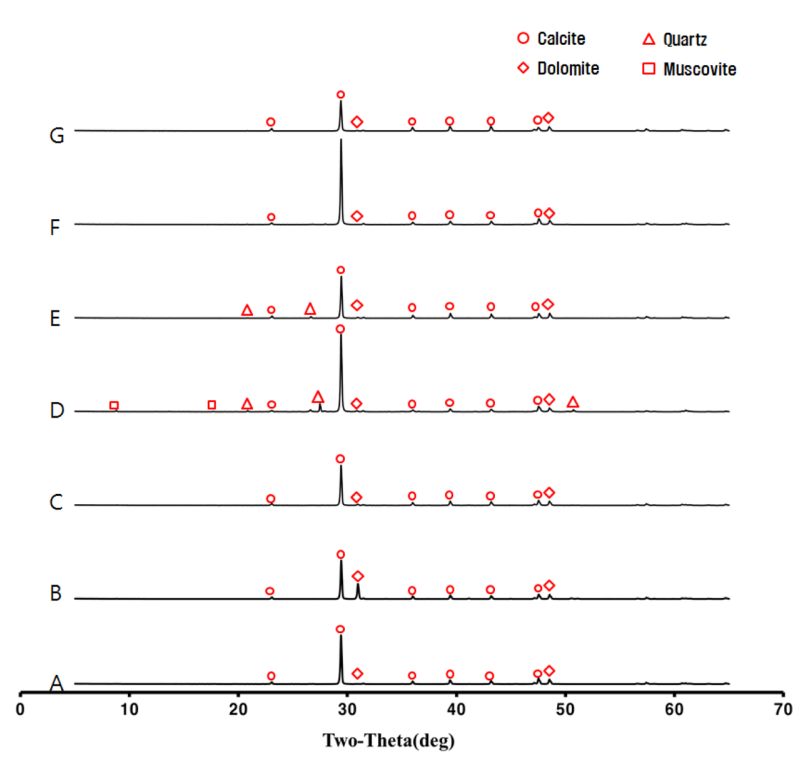

Fig. 3. XRD patterns of limestone samples.

\& E samples among 5 domestic samples were very similar, desulfurizing oxidation was ended at a relatively low temperature in the case of B, C and D samples. Among these, A and $\mathrm{C}$ samples which were geographically adjacent and very similar chemically can be affirmed to have had occurrence of a difference in thermal decomposition characteristics, which is attributable to the occurrence of fine content differences in the component mineral phases and of differences in pore formation characteristics, heat transfer rates of limestone and in diffusion characteristics of carbon dioxide. ${ }^{11)}$ In the case of D sample, as it not only contained a large amount of Quartz $\left(\mathrm{SiO}_{2}\right)$ as an impurity but also had very irregular crystal sizes, thermal decomposition rates could be affirmed to be increased in comparison with other samples, and a weight reduction rate of $35 \%$ was observed which was lower 


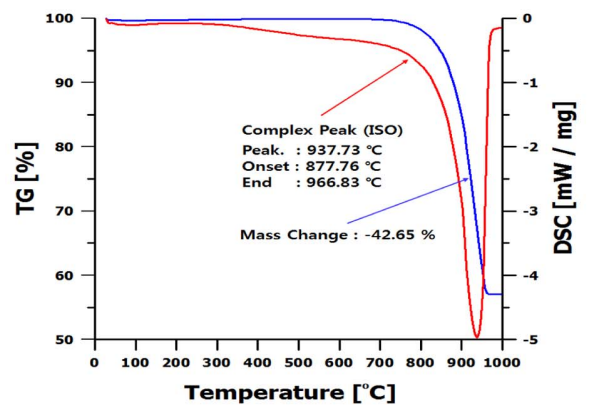

(A)

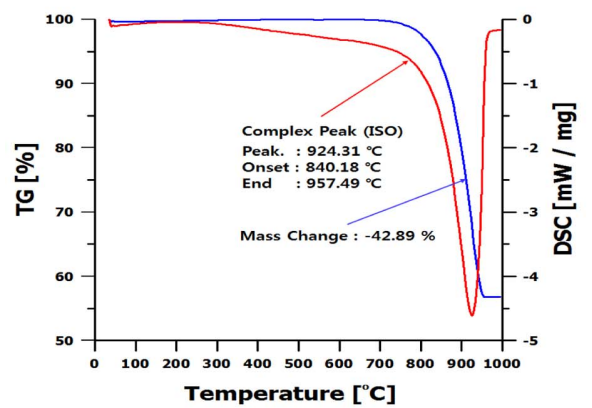

(C)

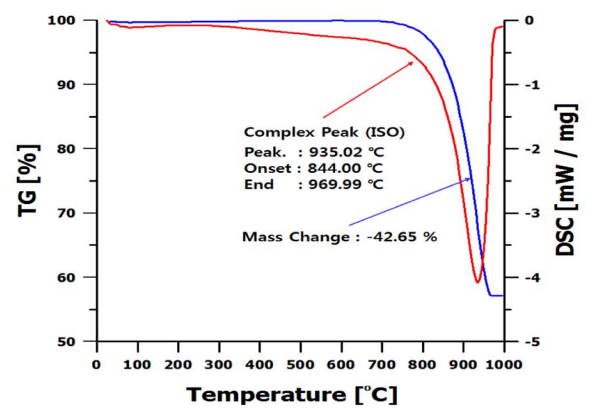

(E)

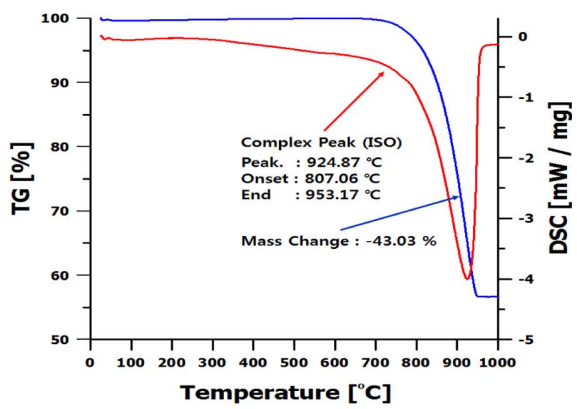

(B)

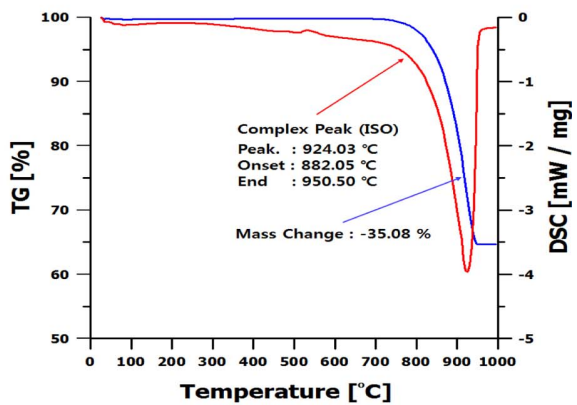

(D)

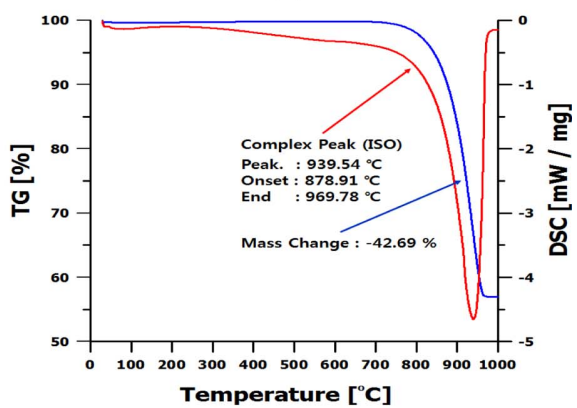

(F)

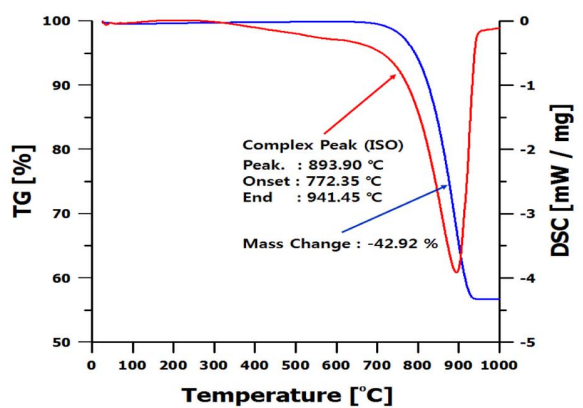

$(G)$

Fig. 4. TG-DSC analysis results of limestone samples.

than that for 4 other samples(about $43 \%$ ) by about $8 \%$. While 2 overseas (F-G) samples had a constant weight reduction rate despite of being a high-class limestone with more than $54 \%$ of $\mathrm{CaO}$ content, endothermic peak temperature was $939^{\circ} \mathrm{C}$ for $\mathrm{F}$ sample and $893^{\circ} \mathrm{C}$ for $\mathrm{G}$ sample, exhibiting a large difference. As with the optical microscope analysis results, this suggests that the temperature difference was brought about since the thermal decomposition rate was increased in $\mathrm{G}$ sample due to its fine grain sizes whereas the thermal decomposition rate was decreased in $\mathrm{F}$ sample due to its coarse grain sizes.

\subsection{Calcination characteristics analysis for limestone}

For the surface analysis after calcination, the samples were processed to a rectangular parallelepiped and ground, followed by calcination, and some of the calcined face was 
cut off for SEM analysis as shown in Fig. 5. In the case of A and $\mathrm{C}$ samples, a shrunk core of a constant sphere form could be affirmed at $850^{\circ} \mathrm{C}$, and deformation of crystals and an increase in plugging phenomenon could be seen as the calcination temperature was increased. In the case of $\mathrm{B}$ sample, the shapes of the core as a function of calcination temperature were close to a rod type, while some uncalcined faces were observed at $850^{\circ} \mathrm{C}$ and continued pore expansion was also observed at $1,050^{\circ} \mathrm{C}$ so that desulfurization reaction characteristics below $900^{\circ} \mathrm{C}$ were expected to be relatively low. In the case of $\mathrm{D}$ sample, although the core shape had a characteristic of being formed into a rod appearance
(A)

(B)

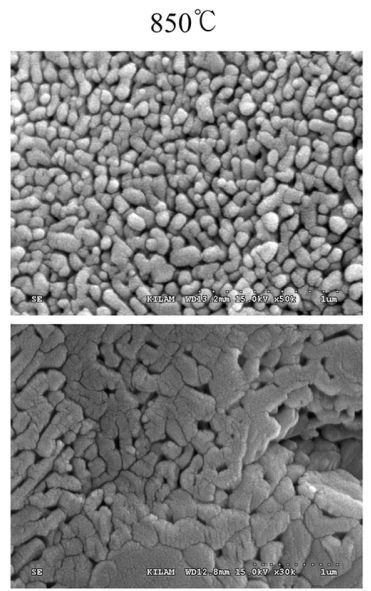

(C)

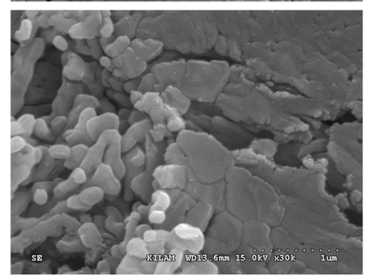

(D)

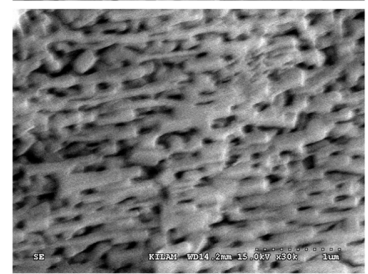

(E)

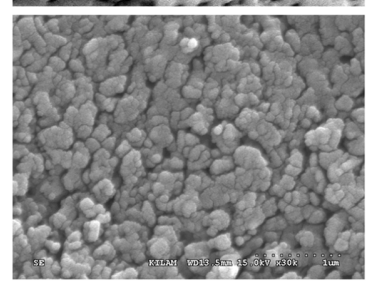

(F)

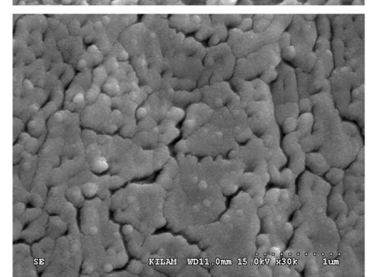

(G)

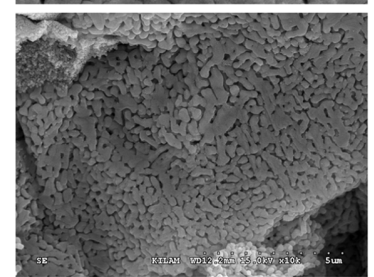

$950^{\circ} \mathrm{C}$
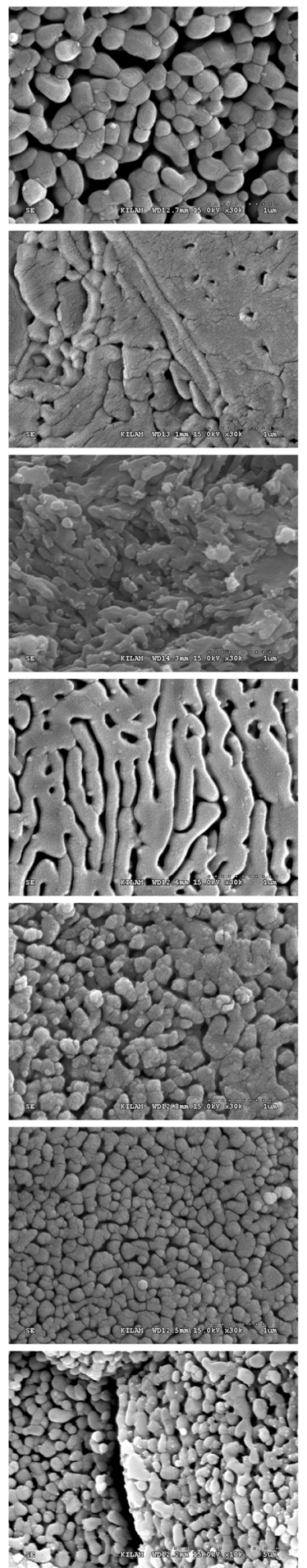

$1,050^{\circ} \mathrm{C}$
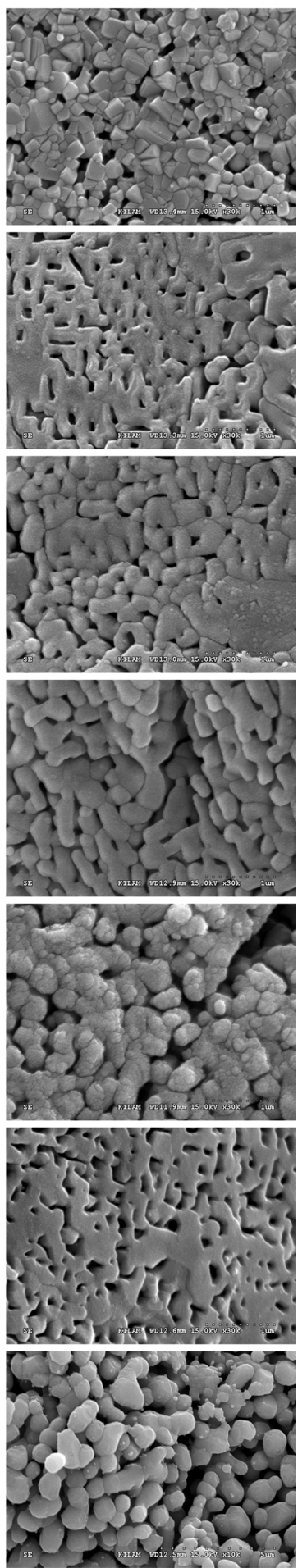

Fig. 5. Surface images of limestone samples by different calcination temperatures. 
Table 3. Total Pore Area and Porosity of Limestone Samples with Different Calcination Temperature

\begin{tabular}{|c|c|c|c|c|c|c|}
\hline & \multicolumn{6}{|c|}{ Calcination Temperature } \\
\hline & \multicolumn{2}{|l|}{$850^{\circ} \mathrm{C}$} & \multicolumn{2}{|l|}{$950^{\circ} \mathrm{C}$} & \multicolumn{2}{|l|}{$1,050^{\circ} \mathrm{C}$} \\
\hline & Total Pore Area $\left(\mathrm{m}^{2} / \mathrm{g}\right)$ & Porosity (\%) & Total Pore Area $\left(\mathrm{m}^{2} / \mathrm{g}\right)$ & Porosity (\%) & Total Pore Area $\left(\mathrm{m}^{2} / \mathrm{g}\right)$ & Porosity (\%) \\
\hline A & 3.86 & 13.85 & 13.26 & 45.38 & 9.20 & 42.57 \\
\hline B & 9.68 & 32.97 & 16.24 & 40.16 & 8.05 & 40.29 \\
\hline $\mathrm{C}$ & 10.20 & 25.54 & 14.57 & 44.51 & 9.83 & 59.63 \\
\hline $\mathrm{D}$ & 1.33 & 7.96 & 12.90 & 48.56 & 12.76 & 38.20 \\
\hline $\mathrm{E}$ & 3.39 & 16.79 & 7.25 & 46.33 & 3.50 & 31.73 \\
\hline $\mathrm{F}$ & 9.15 & 32.79 & 9.25 & 49.36 & 6.09 & 45.64 \\
\hline G & 11.23 & 38.19 & 2.98 & 52.79 & 1.42 & 50.43 \\
\hline
\end{tabular}

in the section of $950^{\circ} \mathrm{C}$ as with $\mathrm{C}$ sample, the core shape and the pore distribution could be affirmed to become the more favorable, the higher the calcination temperature. In the case of $\mathrm{E}$ sample having microcrystalline structures, the distributed amounts of pores were affirmed to be small under the calcination temperature conditions excluding $950^{\circ} \mathrm{C}$ according to the analysis results in connection with pore distribution characteristics, and hence the temperature width for the occurrence of formation and deformation of the core was so small that its precise control deemed necessary. In the case of $\mathrm{F}$ sample, although pore formation was not observed to be completed in the calcination section of $850^{\circ} \mathrm{C}$, relatively fine formation of grains occurred under the calcination condition of $950^{\circ} \mathrm{C}$ and the tendency for pore reduction at $1,050^{\circ} \mathrm{C}$ was also small so that high initial desulfurization efficiencies are expected to be provided. In the case of $\mathrm{G}$ sample, relatively active formation of a linear core was affirmed to be realized from $850^{\circ} \mathrm{C}$ and up, and no agglomeration phenomenon of crystals was observed at $1,050^{\circ} \mathrm{C}$, either, exhibiting a different tendency from that of E sample as a similar microcrystalline calcite.

Measured results for the pore characteristics as a function of calcination temperature are shown in Table 3. Although most limestone samples employed for calcination showed high porosities at $950^{\circ} \mathrm{C}$, some samples showed a phenomenon of porosity reduction due to welding and melting at $1,050^{\circ} \mathrm{C}$. In the case of crystalline limestone of $\mathrm{C}$ and $\mathrm{F}$ samples, although pores of a relatively small proportion are formed at $850^{\circ} \mathrm{C}$, pore formation was active under the calcination conditions above $950^{\circ} \mathrm{C}$ so as to be considered advantageous to the in-furnace desulfurization reaction. However, in $\mathrm{E}$ sample where crystal sizes were relatively small, porosities were greatly reduced at $1,050^{\circ} \mathrm{C}$ according to the porosity measurement results as in the SEM analysis results. In the case of G sample, it was affirmed to have very excellent pore-forming characteristics unlike $\mathrm{E}$ sample of similar crystal sizes, and thus the impact of pore-forming characteristics on the crystal sizes could be expected to be low.

\subsection{Analysis of desulfurization performance for limestone}

Prior to measurement of desulfurization performance for limestone samples, total neutralization capacity (TNC) was evaluated by using regent-grade calcium carbonate (Sigma Aldrich BioX) and industrial slaked lime as the control group. In the case of added amount of $\mathrm{HCl}$ required for two samples to maintain $\mathrm{pH} 6 \pm 0.4$ for 30 minutes, the regentgrade calcium carbonate was affirmed to have a mean TNC of 5.88 ( $\mathrm{HCl} 2.93 \sim 2.96 \mathrm{~mL}$ ), and the industrial slaked lime a mean TNC of 61.57 ( $\mathrm{HCl} 60.35 \sim 62.36 \mathrm{~mL})$. And in an overseas study utilizing the ASTM test method, a mean TNC value for 28 types of limestones was surveyed to be 4.86 with a mean TNC value for the upper 10 limestones being $5.86 .{ }^{12)}$

Mean TNC values for 21 samples including 7 types of limestone as analysis object and classified per particle size are shown in Fig. 6. While $\mathrm{A}$ and $\mathrm{C}$ samples as Pungchon formation limestone had almost similar crystal forms mineralogically, $\mathrm{C}$ limestone having a high $\mathrm{MgO}$ content known to enhance reactivities when crystal sizes are small and its contents are less than $3 \%$ showed a slightly high measured TNC as a whole. ${ }^{13)}$ For D and F samples with larger crystals

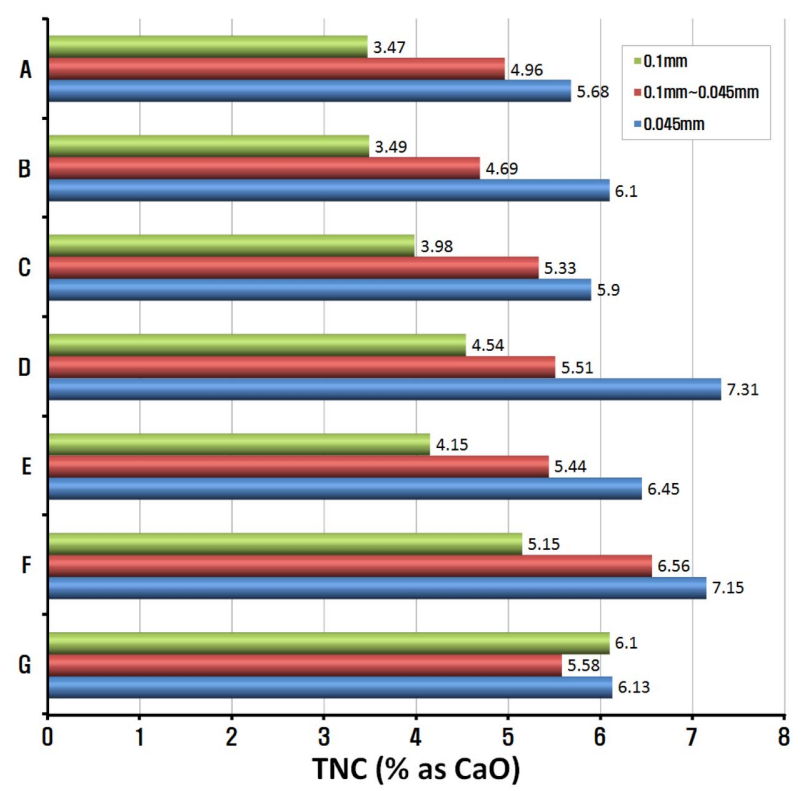

Fig. 6. The effect of TNC with different particle size in limestone samples. 
as compared with B sample which exhibited the lowest desulfurization characteristics, very excellent desulfurization characteristics were measured presumably due to the particle shape and size formed in pulverization process. In the case of $\mathrm{E}$ sample with relatively small crystal sizes, higher TNC was measured than with microcrystalline G sample, so that the former is expected to be suitable for application to wet desulfurization. Consequently, desulfurization performance of the limestone together with its chemical composition are expected to have greater effects on the characteristics of particle size and shape in physical pulverization process. ${ }^{14)}$

\section{Conclusions}

By conducting analyses of physicochemical characteristics and evaluations of calcination characteristics together with desulfurization performance for the object of 7 types of limestone samples with different generation ages and crystal sizes, the following results could be obtained.

- In terms of the pores of limestone generated in calcination process, A and $\mathrm{C}$ samples as Pungchon formation limestone had high porosities according to SEM and porosity analyses, making them suitable for in-furnace desulfurization process, while $\mathrm{E}$ and $\mathrm{F}$ samples had a high TNC allowing expectation as a limestone suitable for application to wet desulfurization.

- Since differences in desulfurization characteristics of limestones occur as a result of having diversified chemical compositions and crystals and also as a function of process methods, the applications should be secured according to the mineral characteristics and the features in chemical composition.

\section{Acknowledgments}

This research was conducted in 2015 with support from the Energy Technology Development Project [20141010101880] of the Korea Institute of Energy Technology Evaluation and Planning, financed by the Ministry of Trade Industry and Energy.

\section{REFERENCES}

1. J. B. Park and J. H. Roh, "Scenario Analysis of Natural Gas
Demand for Electricity Generation in Korea," Trans. KIEE., 63 [11] 1503-10 (2014).

2. J. K. Kim and H. D. Lee, "Combustion Characteristics of High Moisture Indonesia Coal as a Pulverized Fuel at Thermal Power Plant," J. Energy Eng., 19 [2] 136-42 (2010).

3. J. S. Kim and J. M. Lee, "A Study on Design Characteristics of Yeosu Circulating Fluidized Bed Boiler," J. Korean Soc. Combust., 16 [1] 1-7 (2011).

4. K. Dam-Johanson and K. Ostergaard, "High Temperature Reaction between Sulphur Dioxide and Limestone-I. Comparison of Limestones in Two Laboratory Reactors and a Pilot Plant," Chem. Eng. Sci., 46 [3] 827-37 (1991).

5. R. K. Srivastava and W. Jozewicz, "Flue Gas Desulfurization: The State of the Art," J. Air Waste Manage., 51 167688 (2001).

6. D. W. Marsh and D. L. Ulrichson, "Rate and Diffusional Study of the Reaction of Calcium Oxide with Sulfur Dioxide," Chem. Eng. Sci., 40 [3] 423-33 (1985).

7. T. Doğu, "The Importance of Pore Structure and Diffusion in the Kinetics of Gas-Solid Non-Catalytic Reactions: Reaction of Calcined Limestone with $\mathrm{SO}_{2}$," Chem. Eng. J., 21 [3] 213-22 (1981).

8. S. K. Bhatia and D. D. Perlmuttcr, "A Random Pore Model for Fluid-Solid Reactions: II. Diffusion and Transport Effects," AlChE. J., 27 [2] 247-54 (1981).

9. P. G. Christman and T. F. Edgar, "Distributed Pore-Size Model for Sulfation of Limestone," AlChE. J., 29 [3] 388-95 (1983).

10. ASTM C1318-95, "Standard Test Method for Determination of Total Neutralizing Capability and Dissolved Calcium and Magnesium Oxide in Lime for Flue Gas Desulfurization (FGD)", ASTM International. (2001).

11. A. W. D. Hill, "The Mechanism of the Thermal Decomposition of Calcium Carbonate," Chem. Eng. Sci., 23 [4] 297320 (1968).

12. Illinois Clean Coal Institute, Lime Softening Sludge-A Potentially Important Source of Sorbents for Wet FGD Systems (ICCI Project No. 11/6D2, 2012, www.icci.org/reports/ 11Lasemi6D-2.pdf).

13. R. O. K. Ministry of Trade Industry and Energy, Development of Utilization Technology of DBA and Domestic Limestone in Flue Gas Desulfurization Process (MOTIE Project No. 2000-C-CT01-P03 2002, www.nanet.go.kr).

14. J. H. Noh, "Applied-Mineralogical Study on the Mineral Facies and Characteristics of Domestic High-ca Limestone," J. Miner. Soc. Korea, 17 [4] 339-55 (2004). 